\title{
POLITIK HUKUM JANGKA WAKTU PENUNDAAN KEWAJIBAN PEMBAYARAN UTANG DI INDONESIA
}

\author{
Sumurung P. Simaremare ${ }^{1+2}$, Bismar Nasution ${ }^{1}$, Sunarmi $^{1}$, Edi Yunara ${ }^{1}$ \\ ${ }^{1}$ Fakultas Hukum, Universitas Sumatera Utara, Medan \\ ${ }^{2}$ Kejaksaan Republik Indonesia, Jakarta \\ sumurungpsimaremare@gmail.com
}

\begin{abstract}
Abstrak
Adanya penelitian ini untuk menganalisa penetapan batas waktu penyelesaian perkara pembayaran utang yang berlatar belakang politik hukum. Sejak UUKPKPU diundangkan 16 tahun yang lalu, perkembangan UUKPKPU sangat rapuh, sehingga penelitian ini sangat diperlukan. Menghadapi tantangan perekonomian nasional saat ini, pelaku usaha dan pakar hukum mengkritisi UUKPKPU terlalu singkat. Selain itu, adanya periode ini masih membuka ruang bagi kreditor dan debitur untuk melakukan fraud. Berdasarkan studi hukum normatif, kesimpulan yang didapakan yaitu: 1) Secara hukum, ketentuan Indonesia yang ditangguhkan mengenai kewajiban pembayaran utang diawasi oleh UUKPKPU. Pada prinsipnya PKPU sendiri dianggap dapat meringankan keterlambatan pembayaran hutang debitur. Harapan debitur memperoleh penghasilan yang cukup untuk melunasi seluruh utangnya dalam waktu yang relatif singkat; 2) baik kreditur dan debitur dalam Kerangka PKPU Pemberian waktu yang sangat singkat untuk penyelesaian kesepakatan damai kedua belah pihak dapat menyebabkan kedua belah pihak ingin mencapai kesepakatan perdamaian yang kurang optimal.
\end{abstract}

Kata kunci: Politik Hukum; Jangka Waktu; Penundaan Utang. 


\title{
LEGAL POLITICS OF DELAY TERMS DEBT PAYMENT OBLIGATIONS IN INDONESIA
}

\begin{abstract}
This study aims to explore the intent of determining the time frame for settlement of cases of postponement of debt payment obligations in the context of legal politics. This research needs to be discussed because sixteen years after its promulgation, the UUKPKPU began to look fragile in facing the challenges of the current national economy. One aspect that has started to be criticized by business players and legal experts is that the time frame given by the UUKPKPU is considered too short. In addition, the existence of this period of time still opens up space for fraud, both by creditors and by debtors. Based on normative legal research, the authors draw the following conclusions: 1) juridically, the regulation of postponement of debt payment obligations in Indonesia is regulated through the UUKPKPU. In principle, PKPU itself is recognized as relief given to debtors to delay payment of their debts, the debtor hopes that in a relatively short time he will get sufficient income to pay off all his debts; 2) The provision of a very short time for the settlement of a peace agreement between creditors and debtors within the framework of PKPU has the potential to be less than optimal for the peace agreement that both parties want to achieve.
\end{abstract}

Keywords: Legal Politics; Delay Term; Suspension of Payment. 


\section{PENDAHULUAN}

\section{A. Latar Belakang}

Krisis mata uang di Indonesia pada tahun 1998 membawa kesulitan yang sangat besar bagi perekonomian dan perdagangan nasional, yang berdampak pada perkembangan usaha masyarakat, bahkan menyulitkan kegiatan usahanya yang juga sangat mempengaruhi perkembangan usaha. Kemampuan pengusaha untuk memenuhi kewajiban pembayaran hutang sangat sedikit. ${ }^{1}$

Menurut alinea keempat Pembukaan Undang-Undang Dasar Negara Republik Indonesia Tahun 1945 dan Pancasila, pembangunan hukum nasional untuk mewujudkan masyarakat adil dan makmur ditujukan untuk mewujudkan sistem hukum nasional melalui pembentukan undang-undang baru, khususnya hukum. Produk, yang diperlukan untuk mendukung pembangunan ekonomi warga. ${ }^{2}$ Undang-undang kepailitan merupakan salah satu solusi untuk pembangunan ekonomi skala besar masalah hutang perusahaan sangat berguna untuk memenuhi kebutuhan hukum para pelaku usaha untuk mengatasi masalah hutang dan perkreditan. ${ }^{3}$

Sejak 1905, organisasi Kepailitan Indonesia telah ada dalam bentuk faillisements-Verordening Staatsblaad No.1 1905. 217 Juncto Staatsblaad 1906 No.348 (FV). Namun krisis mata uang Indonesia pada tahun 1997-1998 mengguncang perekonomian nasional dan memaksa terjadinya perubahan besar. Guna membantu dunia usaha segera menyelesaikan masalah pinjaman, Pemerintah Republik Indonesia telah mengeluarkan peraturan pemerintah alternatif. Undang-undang tentang pailit tanggal 1 Januari 1998 kemudian

\footnotetext{
${ }^{1}$ Adriel Michael Tirayo, Yoefanca Halim, "Problematik Definisi Harta Pailit Untuk Mencapai Kepastian Hukum Dalam Pelaksanaan Kepailitan dan PKPU”, Jurnal Ilmiah Penegakan Hukum”, 6 (2), 2019, hlm.131.

2 Doni Budiono, “Analisis Pengaturan Hukum Acara Kepailitan Dan Penundaan Kewajiban Pembayaran Utang”, JHAPER, 4 (2), 2018 hlm. 110.

3 Kheriah, "Independensi Pengurus Penundaan Kewajiban Pembayaran Utang (PKPU) Dalam Hukum Kepailitan”, Jurnal Ilmu Hukum, 3 (2), 2013, hlm. 239.
} 
dikukuhkan menjadi Undang-Undang Nomor 1 tentang Kepailitan tanggal 22 April 1998 (selanjutnya disebut UUK).

Sesuai dengan ketentuan UUK, muncul harapan agar kredit macet dapat diselesaikan melalui prosedur pailit yang sangat menguntungkan pelaku usaha. Kebangkrutan memang tidak menjadi perhatian publik, juga tidak menarik, tetapi tiba-tiba menjadi proses likuidasi pinjaman yang bermasalah, dan pelaku usaha sangat membutuhkannya. Hal ini dibuktikan dengan meningkatnya jumlah permohonan pailit yang diajukan kepada Pengadilan Niaga Pusat Jakarta menjadi 100 perkara pailit yang diajukan pada tahun 1999.

Awalnya, dunia usaha sangat berharap peradilan niaga dapat menyelesaikan perkara yang masuk dengan cepat, transparan, dan adil. Namun dalam perkembangannya, peradilan niaga mengalami banyak kendala dalam menjalankan tugasnya sehingga hasil pelaksanaannya tidak maksimal. Situasi ini telah mengecewakan pelaku usaha dan mengurangi minatnya dalam menjalankan tugasnya guna menyelesaikan proses kebangkrutan yang dihadapkan pada permasalahan kredit bermasalah.

Mengingat UUK dinilai tidak mampu mengakomodir kepentingan bisnis dan tidak dapat mengatasi hambatan dalam pelaksanaannya, maka Undang-Undang Nomor Nomor 37 Tahun 2004 mengatur tentang kepailitan dan kewajiban penyelesaian utang (selanjutnya disebut UUKPKPU). Sejak diundangkan, sudah sekitar 16 tahun lamanya, karena kekurangan di berbagai daerah, UUKPKPU rentan terhadap tantangan perekonomian nasional saat ini. Satu hal yang mulai dikritik para pebisnis mengenai durasi yang diberikan UUKPKPU dinilai terlalu pendek.

Fakta biasanya menunjukkan bahwa kemungkinan perdamaian dalam proses kebangkrutan Indonesia dan PKPU masih sangat kecil. Bahkan Undang-Undang Nomor 37 Tahun 2004 memberikan fasilitas penyelesaian secara damai baik dalam proses kepailitan maupun dalam proses PKPU. Undang-Undang Nomor 37 Tahun 2004 belum mendefinisikan perdamaian, tetapi untuk pemahaman umum dapat dipandang melalui Pasal 222 Undang-Undang Nomor 37 Tahun 2004. Pada prinsipnya, rencan pembayaran 
mencakup usulan untuk membayar kembali sebagian atau seluruh hutang kepada kreditor. ${ }^{4}$

Ada banyak faktor-faktor yang mendorong permintaan perubahan undang-undang kebangkrutan serta menunda pembayaran utang, termasuk: Pertama, jika beberapa kreditor menagih utang pada saat yang sama, hindari perilaku aset debitur. Kedua, perlu menghindari situasi di mana jaminan yang dipegang kreditor utama mengklaim dengan menjual haknya properti debitur Terlepas dari kepentingan debitur, atau kreditor lain. Ketiga, hindari penipuan baik itu oleh kreditur atau debitur. ${ }^{5}$

Sejalan dengan hal tersebut, artikel ini berupaya mencari jawaban atas hasil penelitian sebelumnya yang mungkin dilakukan oleh penelitian-penelitian hukum lainnya. Namun, studi sebelumnya ini telah menekankan poinnya masing-masing, yang sama sekali berbeda dari pekerjaan yang akan diselesaikan dalam artikel ini. Hasilnya, beberapa penelitian sebelumnya dapat diartikan sebagai bacaan pendahuluan, dan penelitian ini juga dapat diartikan sebagai pelengkap penelitian sebelumnya. Penelitian sebelumnya yang dikutip dalam artikel ini termasuk penelitian yang dilakukan oleh Novitasari yang mengangkat permasalahan hukum terkait dengan ketentuan yang terdapat dalam UUKPKPU, yaitu terkait batas waktu singkat PKPU yang menjadi penyebab gagalnya batas waktu tersebut. Perdamaian antara debitur dan kreditur. Dalam rangkumannya, Novitasari mengemukakan bahwa singkatnya waktu terhadap debitur dan kreditor dalam berdamai justru membuat debitor sulit mencapai kesepakatan melalui upaya damai. ${ }^{6}$

Penelitian Astara juga mengungkapkan hal yang sama, yaitu mengangkat persoalan penundaan pembayaran utang dari sudut pandang empiris, yaitu menganalisis putusan Pengadilan Niaga Nomor 20: Pailit / 2011 /

${ }^{4}$ F. Yudhi Priyo Amboro, "Restrukturisasi Utang Terhadap Perusahaan Go Public Dalam Kepailitan Dan PKPU”, Jurnal Masalah-Masalah Hukum”, 49 (1) , 2020, hlm. 104.

5 Catur Irianto, "Penerapan Asas Kelangsungan Usaha Dalam Penyelesaian Perkara Kepailitan Dan Penundaan Kewajiban Pembayaraan Utang (PKPU)”, Jurnal Hukum dan Peradilan, 4 (3), 2015, hlm. 400.

${ }^{6}$ Novitasari, "Tinjauan Yuridis Pembatasan Jangka Waktu Penundaan Kewajiban Pembayaran Utang Terhadap Debitor”, Jurnal Kertha Patrika, 39 (2), 2017, hlm 89-107. 
PN.NIAGA.SBY. Penelitian Astara menyimpulkan PKPU dalam proses kepailitan tidak ada artinya, terutama untuk kasus dugaan pelanggaran kontrak dan penipuan yang memerlukan pertimbangan menyeluruh dan komprehensif, termasuk hukum perdata dan pidana. ${ }^{7}$

Penelitian selanjutnya mempertanyakan efektivitas lembaga untuk menunda kewajiban pembayaran hutang untuk mencegah debitur dari kebangkrutan. Dalam studi tersebut, Sagala menyimpulkan bahwa debitur sangat mudah bangkrut atau debiturnya bangkrut, dan PKPU tidak dapat mengambil langkah lain, namun kalaupun kebangkrutan dapat dihindari, sulit bagi kreditor untuk mengambil peran yang menentukan. ${ }^{8}$ Atas dasar melanjutkan penelitian sebelumnya, artikel ini bertujuan untuk mengeksplorasi maksud dan tujuan penentuan jangka waktu penyelesaian permasalahan penundaan kewajiban pembayaran utang dalam konteks politk hukum.

\section{B. Perumusan Permasalahan}

Dengan bertitik tolak dari permasalahan di atas maka dirumuskan dua rumusan permasalahan, yaitu:

1. Bagaimana pengaturan penundaan kewajiban pembayaran utang dalam hukum positif di Indonesia?

2. Bagaimana politik hukum jangka waktu penyelesaian perkara penundaan kewajiban pembayaran utang di Indonesia?

\section{Metode Penelitian}

Studi yang dilakukan dalam penelitian ini termasuk dalam kategori stud $\mathrm{i}$ doktrinal. ${ }^{9}$ Penelitian hukum doktrinal adalah ilmu hukum yang dirumuskan dan dikonseptualisasikan berdasarkan doktrin-doktrin yang diikuti oleh

\footnotetext{
${ }^{7}$ I Wayan Wesna Astara, "Penundaan Kewajiban Pembayaran Utang dalam Kepailitan (Analisis Terhadap Putusan Pengadilan Niaga Nomor: 20/Pailit/2011/PN.Niaga.SBY)”, Jurnal Magister Hukum Uday ana, 4(2), 2015, hlm 408-421.

8 Elviana Sagala, "Efektifitas Lembaga Penundaan Kewajiban Pembayaran Utang Untuk Menghindarkan Debitur Dari Pailit”, Jurnal Ilmiah Advokasi, 3 (1), 2015, hlm: 39-56.

9 "Di Indonesia, metode doktrinal ini terlanjur secara lazim disebut sebagai metode penelitian yang normatif, untuk dilawankan dengan metode penelitian yang dikatakan terbilang empiris (yang didalam literatur internasional disebut sebagai penelitian nondoktrinal)".
} 
pembuat konsep dan/atau pengembang. ${ }^{10}$ Studi ini juga identik dengan penelitian norma yuridis, dalam penelitian hukum jenis penelitian tersebut menekankan pada penelitian pustaka, bahan yang digunakan akan diperoleh dari hukum dan media massa, dan bahan tersebut berkaitan dengan bahan tertulis. $^{11}$

Studi ini menggunakan data sekunder karena penelitian yang dilakukan termasuk penelitian doktrinal dengan Undang-Undang Nomor 37 Tahun 2004 tentang kepailitan dan penundaan kewajiban pembayaran utang sebagai bahan hukum utama. Selain itu, permasalahan pada studi ini akan diselesaikan dengan menggunakan dua jenis metode, yaitu metode pendekatan perundang-undangan dan perbandingan.

Pendekatan "hukum yang berlaku secara umum" dilaksanakan dengan mengkaji semua hukum dan regulasi berkaitan dengan persoalan yang diteliti. Hasil penelitian ini memberikan dasar untuk memecahkan masalah langsung. ${ }^{12}$

\section{PEMBAHASAN}

\section{A. Pengaturan Penundaan Ke wajiban Pembayaran Utang dalam Hukum Positif di Indonesia}

PKPU adalah keringanan yang memberi debitur penundaan pembayaran hutangnya, debitor berharap dalam waktu yang relatif singkat ia mendapatkan penghasilan yang cukup untuk melunasi seluruh hutangnya. ${ }^{13}$ Para debitur mulai menyadari bahwa situasi keuangan mereka buruk, yang menghalangi mereka untuk membiayai hutang mereka dan dapat memilih opsi lain untuk menyelamatkan situasi mereka. Beberapa pilihan yang terlibat meliputi: ${ }^{14}$

\footnotetext{
10 Soetandyo Wignjosoebroto, 2002, "Hukum: Paradigma, Metode dan Dinamika Masalahnya, Elsam-Huma, Jakarta", hlm. 147-148.

11 Sumurung P. Simaremare, Muhammad Dzikirullah H. Noho, "Disharmonized the Regulation of Biological Resources and its Ecosystem in Indonesia”, International Journal of Criminology and Sociology, 10, 2021, hlm. 336

12 Ibid, hlm. 93.

${ }^{13}$ Robinton Sulaiman, Joko Prabowo, 2000, "Lebih Jauh Tentang Kepailitan (Tinjauan Yuridis Tanggung Jawab Komisaris, Direksi dan Pemegang Saham Terhadap Perusahaan Pailit”, Fakultas Hukum Universitas Pelita Harap an Karawaci, hlm. 32.

${ }^{14}$ Man S. Sastrawidjaja, 2006, "Hukum Kepailitan dan Penundaan Kewajiban Pembayaran Utang”, PT. Alumni Bandung, Bandung, hlm. 202.
} 
1. Membangun perdamaian dengan kreditor di luar pengadilan;

2. Jika debitur digugat dengan gugatan perdata, penyelesaian harus dilakukan di pengadilan;

3. Mengajukan penundaan pembayaran utang (PKPU);

4. Mendaftar PKPU untuk perdamaian;

5. Mengajukan permohonan untuk menyatakan bahwa Anda telah dinyatakan pailit oleh pengadilan;

6. Mengajukan kebangkrutan dan perdamaian.

Mengenai alternatif-alternatif tersebut, debitur dapat memilih plihan yang terbaik, dalam hal ini PKPU tampaknya menjadi pilihan yang ideal. Secara hukum, selama tidak ada putusan pailit, PKPU hanya bisa diajukan oleh debitur. Apabila putusan pailit sudah diarahkan pada debitur, debitur tidak dapat mengajukan PKPU. Sedangkan debitur sendiri dapat mengajukan permohonan pailit untuk dirinya sendiri beserta permohonan PKPU, dalam hal ini hakim akan memprioritaskan pemeriksaan PKPU.

Maksud penangguhan atau pelaporan pembayaran adalah waktu yang diberikan oleh undang-undang sesuai dengan keputusan hakim niaga. Selama periode ini, kreditur dan debitur memiliki kesempatan untuk meninjau kembali metode pembayaran utangnya dengan menyediakan seluruh atau sebagian dari rencana pembayaran, termasuk restrukturisasi hutang bila diperlukan. Oleh karena itu, penundaan pembayaran hutang berarti penangguhan atau disebut suspensi hukum. ${ }^{15}$ Tujuan PKPU adalah agar debitur dapat melanjutkan usahanya dan terhindar dari kebangkrutan walaupun pembayarannya sulit. Dengan kata lain pada dasarnya tujuan mengajukan permohonan PKPU adalah untuk mencapai kata damai. Rencana perdamaian yang mencakup tawaran untuk membayar kembali sebagian atau seluruh hutang kepada kreditor. Tujuan pengajuan PKPU adalah:

1. Agar tidak pailit;

2. Adanya ruang kepada debitur untuk melaksanakan usaha tanpa mendesak debitur untuk segera melunasi hutangnya; dan

3. Bisnis yang sehat.

15 Munir Fuady, 2002, "Hukum Pailit", Citra Aditya Bakti, Bandung, hlm. 8. 
Pasal 212 Perpu Nomor. 1 Tahun 1998 yang diatur dalam Undang-Undang No. 4 Tahun 1998 (UUK) menyatakan bahwa debitur yang tidak dapat atau tidak dapat memprediksi bahwa ia tidak akan dapat terus melunasi hutangnya dapat meminta penundaan pembayaran kembali hutangnya. maksudnya adalah untuk mengusulkan perdamaian rencana termasuk penawaran pembayaran, seluruh atau sebagian hutang kepada kreditur merangkap. Mengenai kreditur konkuren memang terdapat perbedaan penamaan antara UUK dan UUKPKPU, seperti terlihat pada tabel berikut:

Tabel 1. Perbedaan Penamaan Kreditor Antara "UU No. 4 Tahun 1998 Tentang Kepailitan” Dengan 'UU No. 37 Tahun 2004 Tentang Kepailitan dan Penundaan Kewajiban Pembayaran Utang"

\begin{tabular}{|c|c|c|}
\hline Perbedaan & $\begin{array}{l}\text { "UU No. } 4 \text { Tahun } 1998 \\
\text { Tentang Kepailitan" }\end{array}$ & $\begin{array}{c}\text { 'UU No. } 37 \text { Tahun } \\
\text { 2004 Tentang } \\
\text { Kepailitan dan } \\
\text { Penundaan Kewajiban } \\
\text { Pembayaran Utang" }\end{array}$ \\
\hline Penamaan Kreditor & Kreditor Konkuren & Kreditor \\
\hline $\begin{array}{l}\text { Memohon Penundaan } \\
\text { Kewajiban } \\
\text { Pembayaran Utang } \\
\text { (PKPU) }\end{array}$ & Debitur & Debitur dan Kreditor \\
\hline
\end{tabular}

Seperti terlihat pada Tabel I, Pasal 222 (2) dan (3) adalah UUKPKPU dengan menunjuk terhadap kreditor, sedangkan UUK menunjuk terhadap kreditor, namun secara prinsip sama. Hal ini sesuai dengan tafsir tentang pengertian "kreditur" dalam Pasal 222 (2), dalam tafsir ini kreditor adalah setiap kreditor, baik secara simultan, preferensial maupun separatis. ${ }^{16}$

Jika UUK menyatakan yang berhak mengajukan PKPU adalah debitur. Dalam UUKPKPU lain, Pasal 222 ayat (1) UUKPKPU mengatur bahwa 'PKPU juga dapat diajukan oleh kreditor. Dalam hal kreditur adalah bank, perusahaan sekuritas, bursa efek, lembaga penjaminan likuidasi, lembaga

${ }^{16}$ Rahayu Hartini, 2007, “Hukum Kepailitan”, UMM Press, Malang,,hlm. 190. 
penyimpanan, perusahaan asuransi, perusahaan reasuransi, dana pensiun, atau badan usaha milik negara yang bergerak di bidang kepentingan umum, maka kreditor yang dapat mengajukan PKPU adalah lembaga”. 17

Permohonan PKPU sebagaimana dimaksud dalam Pasal 222 UUKPKPU "harus diajukan ke pengadilan oleh debitur, ditandatangani oleh debitur, pemohon dan pembela, serta dilampiri dengan daftar yang memuat piutang dan piutang debitur serta sifat hutang, Jumlah dan bukti yang cukup. Jika pemohon adalah kreditur, ia wajib menghubungi debitur melalui pos kilat melalui juru sita dalam waktu tujuh hari sebelum sidang pengadilan. Selanjutnya, debitur mengajukan daftar yang mencantumkan piutang debitur serta sifat dan jumlah hutangnya, bukti yang cukup, dan (jika ada) rencana perdamaian”.

Sekalipun debitur merupakan tergugat pailit, debitur juga dapat mengajukan PKPU. Apabila debitur merupakan perseroan terbatas (PT), debitur dapat mengajukan PKPU dengan jumlah orang yang hadir dalam rapat dan keputusan efektif yang sama setelah mendapat persetujuan rapat umum pemegang saham (RUPS). Dibagi menjadi 2 (dua) tahap, yaitu: ${ }^{18}$

1. Penundaan Sementara Kewajiban Pembayaran Utang

"Bagian awal PKPU, sejak debitur mengajukan permohonan PKPU dan memenuhi berbagai persyaratan administrasi, pengadilan harus menyetujuinya selambat-lambatnya 3 hari sejak tanggal pendaftaran permohonan. Dalam hal permohonan PKPU diajukan oleh kreditor, maka pengadilan harus segera menyetujui permohonan PKPU tersebut dalam waktu 20 hari setelah permohonan diajukan, selain itu pengadilan telah menunjuk hakim pengawas dan menunjuk satu atau lebih pejabat. Pengadilan niaga PKPU harus memutuskan apakah PKPU dapat dilanjutkan sebagai PKPU secara permanen setelah berlangsung maksimal 45 hari”.

2. Penundaan Kewajiban Pembayaran Utang Secara Tetap

17 Ibid, hlm. 191.

18 Lih.penjelasan Pasal 224 UUKPKPU 
Pengadilan niaga akan memanggil debitur dan kreditor terkait untuk hadir di pengadilan melalui pengurus. Di dalam proses persidangan akan diputuskan apakah PKPU dapat diberikan secara permanen, sehingga debitur, pengurus, dan kreditor dapat mempertimbangkan dan menyetujui rencana penyelesaian tersebut. Jika kondisi berikut ini terpenuhi, PKPU dapat disetujui secara permanen:

a) Persetujuan lebih dari setengah jumlah kreditur yang dikonfirmasi atau sementara yang menghadiri rapat, dan setidaknya 2/3 dari total persetujuan atau tagihan sementara dari kreditor atau agen mereka yang hadir pada sidang; dan

b) Piutang dari kreditor yang memperoleh lebih dari setengah piutang, piutang ini dijamin dengan hipotek, jaminan perwalian, hipotek, hipotek atau hak hipotek properti lainnya, keberadaan atau Agen yang menghadiri sidang atas nama setidaknya kreditur atau 2/3 dari klaimnya.

Jika syarat-syarat di atas terpenuhi, maka PKPU dan perpanjangannya melalui nengadilan niaga tidak boleh melebihi 270 hari setelah putusan sementara PKPU diumumkan.

\section{B. Politik Hukum Jangka Waktu Penyelesaian Perkara Penundaan Kewajiban Pembayaran Utang di Indonesia}

Studi politik hukum merupakan salah satu kajian yang paling sering dibicarakan di sektor eksekutif, legis latif dan yudikatif, terutama bagi mereka yang ingin memahami secara kritis dan komprehensif tujuan tertentu dari perundang-undangan melalui pendekatan interdisipliner. ${ }^{19}$ Politik hukum selalu terjalin dan menjadi wilayah negara, baik di pusat maupun di wilayah terkecil negara tersebut. Ekspresi kemauan politik tidak diukur dari "berapa banyak undang-undang yang telah diundangkan", tetapi apakah sebagian besar

19 Syahriza Alkohir Anggoro, "Politik Hukum: Mencari Sejumlah Penjelasan”, Jurnal Cakrawala Hukum 10 (1), 2019, hlm. 78. 
masyarakat Indonesia, terutama yang berasal dari kelas bawah di pedesaan, sudah merasakan peluang "akses keadilan" ini. ${ }^{20}$

Politik hukum itu sendiri dilaksanakan oleh negara, dan kebijakan hukum atau arahan hukum yang ditujukan untuk mencapai tujuan nasional dapat berupa pembuatan undang-undang baru dan penggantian undang-undang lama. Dalam pengertian ini, politik hukum harus berpijak pada tujuan negara dan sistem hukum negara saat ini. Dalam konteks Indonesia, tujuan dan sistem tersebut dicantumkan dalam Pembukaan UUD 1945, khususnya Pancasila. Ini melahirkan pedoman hukum. ${ }^{21}$ Mahfud menyampaikan bahwa dalam proses perkembangan hukum di era reformasi tentunya dibutuhkan politik hukum, yaitu arah kebijakan hukum formal negara. Tentunya sesuai dengan struktur politik era reformasi demokrasi, pembangunan hukum harus merumuskan undang-undang yang sesuai. ${ }^{22}$

Moh. Mahfud MD terbagi menjadi tiga (tiga) kelompok politik hukum, yaitu: Pertama, petunjuk resmi (kebijakan hukum) undang-undang yang akan dilaksanakan untuk mencapai tujuan nasional, termasuk mengganti undang-undang lama dan membentuk undang-undang baru. Kedua, latar belakang politik lahirnya undang-undang dan subsistem sosial lainnya, termasuk petunjuk resmi undang-undang yang akan atau tidak akan ditegakkan; ketiga, isu-isu yang berkaitan dengan penegakan hukum, khususnya garis besar pelaksanaan politik hukum. ${ }^{23}$

Peraturan PKPU didasarkan pada Bab 2 UU Kepailitan 4/1998, bahwa penundaan kewajiban penyelesaian utang (PKPU) atau Surceance van

\footnotetext{
${ }^{20}$ Arif Hidayat, Zaenal Arifin, "Politik Hukum Legislasi Sebagai Socio-Equilibrium Di Indonesia”, Jurnal Ius Constituendum, 4 (2), 2019, hlm. 149.

21 Moh.Mahfud MD, 2011, “Membangun Politik Hukum, Menegakkan Konstitusi”, Cet.ke-2, Rajawali Press, Jakarta, hlm. 5.

${ }^{22}$ Muhammad Dzikirullah H. Noho, "Politik Hukum Pengaturan Build Operate Transfer (BOT) di Indonesia: Di Masa Lalu, Saat Ini, dan Akan Datang”, Jurnal Huku m Media Bhakti, 3 (1), 2019, hlm. 89

${ }_{23}$ Anna Triningsih, "Politik Hukum Pengujian Peraturan Perundang-Undangan dalam Penyelenggaraan Negara”, Jurnal Konstitusi, 13 (1), 2016, hlm. 126.
} 
Belaling atau penangguhan pembayaran. ${ }^{24}$ Pengajuan PKPU dapat dilakukan sebelum atau bersamaan dengan pengajuan pernyataan pailit. Jika PKPU diajukan sebelum mengajukan pernyataan pailit, maka permohonan pernyataan pailit tidak dapat diajukan. Pada saat yang sama, jika PKPU mengajukan permohonan pernyataan pailit yang diperiksa oleh Pengadilan Niaga, maka peninjauan kembali pernyataan pailit tersebut harus dihentikan. ${ }^{25}$

UUK tidak memberikan definisi yang jelas tentang PKPU. Meski demikian, dibandingkan dengan pailit, ciri-ciri PKPU tetap ada, antara lain: ${ }^{26}$

1. Jika debitur tidak dapat melunasi hutangnya yang telah jatuh tempo, buatlah keputusan pailit. Sebaliknya, standar PKPU adalah saat debitur memperkirakan tidak akan bisa melunasi utangnya yang telah jatuh tempo.

2. Kepailitan bertujuan untuk melikuidasi aset debitur yang pailit dan membagi hasilnya di antara kreditor. Di sisi lain, sejauh menyangkut PKPU, tujuannya adalah untuk menjaga integritas aset debitur dan kelangsungan usahanya.

3. Debitur pailit telah kehilangan hak untuk mengelola dan menguasai kekayaan yang termasuk dalam harta pailit sejak diumumkannya putusan pailit; sebaliknya dalam PKPU debitur tidak kehilangan hak untuk mengelola dan mengendalikannya. aktiva. Debitur masih memiliki hak untuk melakukan tindakan manajemen dan mengalihkan hak atas beberapa asetnya, tetapi premisnya adalah bahwa pengalihan hanya dapat dilakukan setelah manajer mengesahkannya.

Dalam konteks politik hukum, terdapat beberapa kendala dalam mengubah Undang-Undang Kepailitan Nomor 4 Tahun 1998 menjadi Undang-Undang Nomor 37 Tahun 2004. Sehubungan dengan perkembangan dan kebutuhan masyarakat yang mendesak, maka isi Undang-Undang

24 "Dikenal juga dengan istilah Suspension of Gbligation for Payment of Debt", Lihat Ricardo Simanjuntak, "Comments on Dr. Vesna Lazic's Paper: The Interaction Between Arbitrarion And Insolvency Proceeding: A Comparative View". dalam "Proceedings, Interaksi Antara Arbitrase dan Proses Kepailitan", Emm)" Yuhassarie, ed., 2004, Pusat Pengkajian Hukum, Jakarta, hlm. 27.

${ }_{25}$ Sutan Remy Sjahdeini, 2010, "Hukum Kepailitan Memahami Undang-Undang No. 37 Tahun 2004 Tentang Kepailitan”, Pustaka Utama Grafiti, Jakarta, hlm. 321.

${ }^{26}$ Fred B.G Tumbuan, "Ciri-ciri Penundaan Kewajiban Pembayaran Utang Sebagairnana Dimaksud dalam Undang-undang Tentang Kepailitan," dalam "Penyelesaian Utang-Piutang Melalui Pailit Atau Penundaan Kewajiban Pembayaran Utang", Rudhy A. Lontoh, S.H., et. aI., ed., Alumni, Bandung, hlm. 243-244. 
Kepailitan (Faillissem entsverordening Staatsblad 1905: 217 juncto Staatsblad 1906: 348) harus diubah dalam Resolusi No. 37 Tahun 2004. Oleh karena itu, Peraturan Pemerintah No. 1 Tahun 1998 Perubahan Undang-Undang Kepailitan yang kemudian ditetapkan menjadi Undang-Undang Nomor 4 Tahun 1998 perlu diganti. Perubahan ini diharapkan dapat memberikan kepastian hukum dan kepastian dalam penyusunan hutang usaha di lingkungan bisnis. Keberadaan Undang-Undang Nomor 37 Tahun 2004 merupakan bagian dari Undang-Undang Nomor 4 Tahun 1998 (tidak terlepas dari Undang-Undang Kepailitan). Selain itu, desakan pembangunan dan perdagangan menjadi semakin pesat, yang tidak dapat diabaikan.

Dalam konteks politik hukum, adapun hal-hal yang melatar belakangi perubahan Undang-Undang Kepailitan No. 4 Tahun 1998 menjadi undang-undang tersebut di mana materi yang terdapat dalam Undang-Undang tentang Kepailitan (Faillissem entsverordening Staatsblad 1905:217 juncto Staatsblad 1906: 348) saatnya untuk diadakan perubahan karena adanya perkembangan dan kebutuhan masyarakat yang mendesak, sehingga Peraturan Pemerintah Nomor 1 Tahun 1998 tentang Perubahan Atas Undang-Undang tentang Kepailitan, yang kemudian ditetapkan menjadi Undang-Undang Nomor 4 Tahun 1998 perlu diganti. Perubahan tersebut harapannya dapat memberikan jaminan dan kepastian hukum dalam perselisihan utang piutang dalam dunia usaha. Adanya Undang-Undang No. 37 Tahun 2004 merupakan bagian yang tidak terpisah dari Undang-Undang Nomor 4 Tahun 1998 tentang Kepailitan. Selain itu juga desakan akan perkembangan dan perdagangan yang semakin pesat, tidak dapat dinafikan begitu saja. Perlu diusulkan regulasi yang menggantikan kepailitan sebagai sarana hukum untuk melindungi kepentingan perekonomian nasional.

Pada Pasal 222 (2), 37/2004 menegaskan bahwa "PKPU adalah legal procedure (atau upaya hukum) yang memberikan hak kepada debitur yang tidak dapat atau tidak dapat memprediksi bahwa mereka tidak akan dapat terus melunasi utangnya pada saat jatuh tempo dan dapat digunakan sebagai hutang untuk membayar hutang". Secara umum, bermaksud untuk mengajukan 
rencana perdamaian, yang mencakup penawaran untuk membayar kembali semua atau sebagian hutang kepada kreditor yang sudah ada.

PKPU dapat diajukan secara sukarela oleh debitur yang telah diprediksi tidak akan dapat melunasi utangnya. Failissementsverordening (FV) memastikan lamanya durasi PKPU menjadi satu setengah tahun. PKPU bisa diperpanjang untuk jangka waktu yang sama, yaitu satu setengah tahun. Jangka waktu ini mulai berlaku sejak tanggal pemberian PKPU sementara. ${ }^{27}$ Ketentuan untuk PKPU sementara harus diberikan oleh pengadilan negeri segera sebelum PKPU masih diberikan, tetapi FV tidak menetapkan batas waktu untuk pembatasan "langsung". Total masa kerja PKPU bisa melebihi 3 tahun. $^{28}$

Sejak Undang-Undang Nomor 4 Tahun 1998 (tentang Perumusan Peraturan Pemerintah Pengganti Undang-Undang Nomor 1 Tahun 1998 (tentang Perubahan Undang-Undang Kepailitan menjadi Undang-Undang), Selanjutnya disebut Undang-Undang Nomor 4 Tahun 1998, jangka waktu akan diperpendek lebih lanjut, yaitu jangka waktu termasuk perpanjangan tidak melebihi 270 (dua ratus tujuh puluh hari) sejak waktu itu, yang mengatur tentang keputusan penundaan. kewajiban pembayaran hutang sementara.

UU No. 4/1998 juga tidak merinci berapa lama batas "langsung" dari hibah PKPU dapat ditentukan. Tujuan perubahan ini sesuai dengan UU 4/1998, dengan cara ini, jangka waktu PKPU dapat ditentukan, dan ada rencana perdamaian yang perlu dibahas dan diputuskan oleh kreditor. Alasan dikeluarkannya Peraturan Pemerintah Nomor 1 Tahun 1998 untuk menggantikan UU Kepailitan adalah untuk menegakkan kepastian hukum bagi kepentingan dunia usaha dalam menyelesaikan permasalahan yang diakibatkan oleh krisis mata uang, sehingga tercapainya penyelesaian rekening yang adil, cepat dan terbuka.

27 Siti Anisah, 2008, "Perlindungan Kepentingan Kreditor dan Debitor Dalam Hukum Kepailitan Di Indonesia”, Total Media, Yogy akarta, hlm. 160.

${ }^{28}$ Ibid. 
Dalam UU Kepailitan, reformasi dilakukan mengenai jangka waktu pendanaan PKPU dan PKPU, UU No. 37/2004 mengatur ketentuan sebagai berikut:

\section{PKPU sementara}

Sebelum pengadilan niaga memutuskan untuk memberikan hibah PKPU secara permanen, baik debitur maupun kreditor dapat mengajukan putusan PKPU sementara sesuai dengan ketentuan Pasal 225 (2), (3) dan (4) UU No. 37/2004 pada dasarnya menjelaskan bahwa jika debitur mengajukan permohonan, pengadilan harus selambat-lambatnya tiga hari sejak tanggal permohonan pendaftaran. Jika permohonan diajukan oleh kreditor, pengadilan selambat-lambatnya dalam waktu dua puluh hari sejak tanggal pendaftaran permohonan. Setelah untuk sementara mengumumkan keputusan penundaan pembayaran hutang, pengadilan akan meminta melalui manajemen untuk memanggil debitur dan kreditur (dikenal sebagai pelanggan terdaftar atau kurir) untuk menghadiri sidang yang akan diadakan selambat-lambatnya sejak keempat puluh lima, keputusan penundaan kewajiban pembayaran hutang tentatif telah diumumkan.

\section{PKPU Tetap}

Untuk menentukan pemberian PKPU kepada debitur secara berkala, maka sidang harus dilaksanakan pada hari empat puluh lima dihitung pasca putusan sementara PKPU yaitu sidang review hakim (rechbank in raddkamer). Dalam hal ini, jika PKPU mendapat persetujuan lebih dari $1 / 2$ kreditor konkuen pada sidang, dan menyumbang minimal $2 / 3$ dari total hak kreditor pada periode yang sama, maka PKPU akan ditetapkan secara permanen oleh komersial. Pengadilan menghadiri atau mewakili sidang. Oleh karena itu, menurut ketentuan ini, tidak adanya kreditor konkuren atau orang yang tidak diwakili dalam persidangan tidak akan mempengaruhi kuorum; selain itu, tidak adanya kreditor konkuren tidak dapat diartikan tidak setuju dengan pemberian Pasal 229 ayat (1) UU No. No. 37/2004 UU. Sejak 
keputusan sementara PKPU dikukuhkan, jangka waktu yang ditentukan tidak boleh melebihi dua ratus tujuh puluh hari.

Sebaliknya, dalam kerangka reorganisasi, di Amerika Serikat, debitur dapat menunda pembayaran tagihan pajak lebih dari enam tahun. Demikian pula, debitur dapat membayar kreditor lebih lama dari yang disepakati sebelumnya, selama pembayarannya sama dengan nilai tagihan saat kreditor memberikan pinjaman. ${ }^{29}$

Sementara di Belanda, jika pelunasan utang masih bisa ditunda, pengadilan negeri (Rechtsbank) menetapkan penundaan pelunasan hingga delapan belas bulan. Jika jangka waktunya telah habis, perpanjangan jangka waktu pembayaran utang dapat diperpanjang hingga delapan belas bulan, dan jangka waktu tersebut dapat diperpanjang kembali setelah berakhirnya setiap jangka waktu. ${ }^{30}$

"Undang-undang Kepailitan" Jerman menetapkan bahwa rencana perdamaian harus menentukan wak tu yang tepat untuk menunda pembayaran utang, tetapi undang-undang tidak menetapkan batas waktu untuk menunda pembayaran utang. ${ }^{31}$

Di Belgia, jangka waktu PKPU yang diatur dengan sistem nilai wajar juga tiga tahun, menurut "Undang-undang Komposisi Peradilan" Belgia tanggal 17 Juli 1997, jika debitur memenuhi persyaratan tertentu, maka komposisi peradilan akan diserahkan kepada debitur. Kedua, terdapat situasi yang membahayakan kelangsungan hidup perusahaan dan dapat mengakibatkan pailit, jika pihak kreditor menyetujui rencana tersebut, pengadilan dapat melanjutkan PKPU selama dua puluh empat bulan, dan jangka waktu PKPU dapat diperpanjang. Sampai bulan, maka jangka waktu PKPU di Belgia adalah 36 bulan. ${ }^{32}$

\footnotetext{
29 Siti Anisah, Op. Cit, hlm. 162.

30 Ibid, hlm. 162.

31 Ibid, hlm. 163.

32 Ibid.
} 
Dalam kerangka PKPU Indonesia, disediakan waktu yang singkat untuk mencapai kesepakatan damai antar kreditur. FV memberikan waktu yang lebih lama bagi debitur untuk mencapai penyelesaian, yang dapat memberikan kewajiban dan peluang kepada debitur nakal. Dokumen UU No. 37/2004 sebenarnya memberikan inisiatif kepada kreditor untuk bekerja sama dengan debitur untuk menyelesaikan metode penyelesaian utang debitur.

Jika dibandingkan dengan Undang-Undang Nomor 37/2004, siklus PKPU Indonesia adalah yang terpendek, yang memberikan waktu yang sangat singkat untuk tercapainya kesepakatan damai antara kreditor dan debitur dalam kerangka PKPU Indonesia, yang memungkinkan terciptanya kesepakatan damai yang semula. Sasaran yang dicapai kreditor dan debitur belum optimal.

Dalam menyusun tenggat waktu PKPU, perusahaan harus mempertimbangkan kemampuan perusahaan dalam memenuhi kewajiban calon debitur. Restrukturisasi perusahaan membutuhkan waktu yang cukup untuk memberikan peluang bagi perusahaan yang masih mempunyai prospek untuk berkembang, berkembang atau melakukan kegiatan usaha, karena debitur memiliki aset yang lebih banyak daripada hutangnya.

Selain pertimbangan di atas, pengaturan waktu PKPU juga harus mempertimbangkan tujuan lain dari UU Kepailitan. Salah satu tujuannya adalah untuk meningkatkan nilai perusahaan yang mengalami kesulitan keuangan namun masih menjanjikan untuk pertumbuhan di masa mendatang. Oleh karena itu, tujuan melindungi mereka yang tidak dapat melindungi dirinya sendiri (pemangku kepentingan) dapat tercapai. Pemberian kesempatan untuk merestrukturisasi usaha debitur berarti akan mengurangi kerugian yang diderita oleh pihak yang mengandalkan kegiatan perusahaan (stakeholders).

\section{PENUTUP}

Berdasarkan pembahasan di atas, maka dapat diambil kesimpulan sebagai berikut: 1) Secara hukum, ketentuan penundaan pembayaran utang Indonesia diatur oleh UUKPKPU. Pada prinsipnya PKPU sendiri dianggap 
dapat meringankan keterlambatan pembayaran hutang debitur, dan debitur berharap mendapatkan penghasilan yang dapat melunasi seluruh utangnya dalam waktu yang relatif singkat. 2) Tujuan pemberian batas waktu PKPU 37/2004 sesuai dengan Undang-Undang Nasional Amerika Serikat No. PK10 adalah untuk memberikan jaminan kepada kreditor bahwa utangnya akan dilunasi, dan jangka waktu utang debitur relatif singkat, sehingga debitur benar-benar dapat melunasi kreditor. Kreditor terkait utang memberikan kontribusi damai sehingga debitur dapat terus menjalankan bisnisnya sendiri tanpa khawatir bangkrut. Jika kita membandingkan tenggat waktu PKPU dalam UU, menurut peraturan No. 37/2004 (berlaku untuk Belanda, Jerman dan Belgia dan peraturan FV), Indonesia memberikan batas waktu PKPU terpendek, yaitu memberikan kreditor dan waktu untuk kreditor. untuk mencapai kesepakatan damai sangatlah singkat. Para debitur dalam kerangka PKPU telah memicu potensi kedua belah pihak untuk mencapai kesepakatan damai yang kurang ideal.

\section{DAFTAR PUSTAKA}

\section{Buku}

Anisah Siti,2008, "Perlindungan Kepentingan Kreditor dan Debitor Dalam Hukum Kepailitan Di Indonesia”, Yogyakarta: Total Media.

Munir Fuady, 2002, "Hukum Pailit", Bandung: Citra Aditya Bakti.

Rahayu Hartini. 2007, "Hukum Kepailitan”, Malang: UMM Press.

Moh.Mahfud MD, "Membangun Politik Hukum, Menegakkan Konstitusi", Cet.ke-2, (Jakarta; Rajawali Pers, 2011).

Man S Sastrawidjaja,2006, "Hukum Kepailitan dan Penundaan Kewajiban Pembayaran Utang", Bandung: PT Alumni.

Ricardo Simanjuntak, 2004, "Comments on Dr. Vesna Lazic's Paper: The interaction Between Arbitrarion and Insolvency Proceeding: A Comparative View". dalam "Proceedings, Interaksi Antara Arbitrase dan Proses Kepailitan", Emm)" Yuhassarie, ed., Jakarta: Pusat Pengkajian Hukum.

Sutan Remy Sjahdeini, 2010, "Hukum Kepailitan Memahami Undang-Undang No. 37 Tahun 2004 Tentang Kepailitan”, Jakarta: Pustaka Utama Grafiti.

Robinton Sulaiman dan Joko Prabowo, 2000, "Lebih Jauh Tentang Kepailitan (Tinjauan Yuridis Tanggung Jawab Komisaris, Direksi dan Pemegang 
Saham Terhadap Perusahaan Pailit', Karawaci: Fakultas Hukum Universitas Pelita Harapan.

Fred B.G Tumbuan, "Penyelesaian Utang-Piutang Melalui Pailit Atau Penundaan Kewajiban Pembayaran Utang”, Rudhy A. Lontoh, S.H., et. aI., ed., Bandung: Alumni.

Soetandyo Wignjosoebroto, 2002, "Hukum: Paradigma, Metode dan Dinamika Masalahnya”, Jakarta: Elsam-Huma.

\section{Jurnal}

Adriel Michael Tirayo, Yoefanca Halim, (2019), "Problematik Definisi Harta Pailit untuk Mencapai Kepastian Hukum dalam Pelaksanaan Kepailitan dan PKPU,,Jurnal Ilmiah Penegakan Hukum, 6 (2).

Arif Hidayat, Zaenal Arifin, (2019), "Politik Hukum Legislasi Sebagai Socio-Equilibrium Di Indonesia", Jurnal Ius Constituendum, 4 (2).

Anna Triningsih, (2016), "Politik Hukum Pengujian Peraturan Perundang-Undangan dalam Penyelenggaraan Negara”, Jurnal Konstitusi, 13 (1).

Catur Irianto, (2015), "Penerapan Asas Kelangsungan Usaha Dalam Penyelesaian Perkara Kepailitan Dan Penundaan Kewajiban Pembayaraan Utang (PKPU)", Jurnal Hukum dan Peradilan, 4 (3).

Doni Budiono, (2018), "Analisis Pengaturan Hukum Acara Kepailitan Dan Penundaan Kewajiban Pembayaran Utang”, JHAPER, 4 (2).

Elviana Sagala, (2015), "Efektifitas Lembaga Penundaan Kewajiban Pembayaran Utang Untuk Menghindarkan Debitur Dari Pailit”, Jurnal Ilmiah Advokasi”, $3(1)$.

F. Yudhi Priyo Amboro, (2020), "Restrukturisasi Utang Terhadap Perusahaan Go Public Dalam Kepailitan Dan PKPU”, Masalah-Masalah Hukum, 49 (1).

I Wayan Wesna Astara, (2015), "Penundaan Kewajiban Pembayaran Utang dalam Kepailitan (Analisis Terhadap Putusan Pengadilan Niaga Nomor: 20/Pailit/2011/PN.Niaga.SBY)", Jurnal Magister Hukum Udayana, 4 (2).

Kheriah, (2013), “Independensi Pengurus Penundaan Kewajiban Pembayaran Utang (Pkpu) Dalam Hukum Kepailitan”, Jurnal Ilmu Hukum, 3 (2).

Muhammad Dzikirullah H. Noho, (2019), "Politik Hukum Pengaturan Build Operate Transfer (BOT) di Indonesia: Di Masa Lalu, Saat Ini, dan Akan Datang”, Jurnal Hukum Media Bhakti, 3 (1).

Novitasari, (2017), "Tinjauan Yuridis Pembatasan Jangka Waktu Penundaan Kewajiban Pembayaran Utang terhadap Debitur, Jurnal Kertha Patrika”, 39 (2).

Sumurung P. Simaremare, Muhammad Dzikirullah H. Noho, (2021), "Disharmonized the Regulation of Biological Resources and its Ecosystem in Indonesia", International Journal of Criminology and Sociology, 10.

Syahriza Alkohir Anggoro, (2019), "Politik Hukum: Mencari Sejumlah Penjelasan", Jurnal Cakrawala Hukum, 10 (1). 